$\mathrm{SAD} / \mathrm{JSR}$

Sosyoloji Araştırmaları Dergisi / Journal of Sociological Research

Cilt / Volume 21 Sayı / Number 2 (Ekim / October 2018) : (86-113)
Araștırma Makelesi / Research Article

Geliş Tarihi / Submited: 26.06.2018

Kabul Tarihi / Accepted: 14.08.2018

\title{
MIGRATORY KITCHEN: THE EXAMPLE OF SYRIANS IN MARDIN
}

\section{Nazife GÜRHAN ${ }^{1}$}

\begin{abstract}
Due to immigration, lifestyle and dietary habits transform depending on the change in the socioeconomic situation, social position, and status of migrants. These changes can be observed in various stages, such as in the availability of food and its preparation, and consumption. This article attempts to demonstrate the transformation in dietary habits after immigration of people who migrated to Turkey since 2011 due to the Syrian war. The study focused on the city of Mardin, located in southeastern Anatolia, and was conducted in the form of fieldwork. Using snowball sampling methods, participant observation, and qualitative research techniques, in-depth interviews were made with 25 people who migrated to Mardin from different regions of Syria. The change in dietary habits varies greatly in parallel with the amount of change in socio-economic status to a large extent. However, there was some differentiation in terms of food structure and diet. This study shows that immigrants' views on food were different. It was observed that Syrians continued their traditional dietary habits or fully adopt the dietary habits of the new country or engage in a hybridization of dietary practices due to cultural transition.
\end{abstract}

Keywords: Immigration, Food, Change, Adaptation, Kitchen Acculturation, Syrian Immigrants.

${ }^{1}$ Dr. Öğr. Üyesi, Mardin Artuklu Üniversitesi, Edebiyat Fakültesi, Sosyoloji Bölümü 


\section{GÖÇ EDEN MUTFAK: MARDIN'DEKİ SURIYYELÍLER ÖRNEĞİ}

\section{ÖZ}

Göç ile birlikte göçmenlerin sosyo-ekonomik durum, toplumsal konum ve statülerindeki değişimlere bağlı olarak yaşam tarzı ve beslenme alışkanlıklarında da değişim meydana gelmektedir. $\mathrm{Bu}$ değişiklikler besinin ulaşılabilirliği, hazırlanması veya tüketimi gibi çeşitli veçhelerde görülebilmektedir. Bu makale, Suriye'de 2011 yılından beri yaşanan savaş nedeniyle ülkelerinden göç ederek Türkiye’ye gelen göçmenlerin göçten sonraki beslenme alışkanlıklarındaki değişim ve dönüşümü ortaya koymaya çalışmaktadır. Araştırma, Güneydoğu Anadolu Bölgesi’nde bulunan Mardin kentine odaklanarak saha çalışması şeklinde yürütülmüştür. Bu bağlamda nitel araştırma teknikleri kullanılarak kartopu örnekleme yöntemiyle Suriye'nin farklı bölgelerinden Mardin'e göç etmiş 25 kişiyle derinlemesine mülakat ve katılımlı gözlem yapılmıştır. Araştırmada beslenme alışkanlıklarındaki değişimin büyük ölçüde sosyo-ekonomik statüdeki farklılaşmaya paralel olarak ortaya çıktığ1 görülmüştür. Bununla birlikte yemeğin yapısı ve beslenme düzeniyle ilgili farklılaşmalar olabilmektedir. Araştırmada göçmenlerin yemek manzaralarının farklı yörüngeler izlediği ortaya çıkmış; Suriyelilerin geleneksel yemek alışkanlıklarını sürdürdükleri veya yeni ülkenin beslenme alışkanlıklarını tamamen benimsedikleri veyahut da kültürel geçişlere bağlı olarak beslenme pratiklerinde melezleşmenin ortaya çıktığı görülmüştür.

Anahtar Kelimeler: Göç, Yemek, Değişim, Uyum, Mutfak Kültürleşmesi, Suriyeli Göçmenler. 


\section{INTRODUCTION}

Today, immigration, which has entered the global agenda, stands for social and cultural movement for economic, political, ecological or individual reasons carried out with the aim of relocation from one place to another (Yalçın, 2004: 13). The phenomenon of migration is a social action that deeply affects the emigrant and immigrant-receiving countries. People who migrate do not only face spatial change in the society in which they live, they also start to live in an unfamiliar, new culture which most of the time brings about social and cultural changes and transformations.

It is known that in recent years the influence of the war in Syria caused a global wave of immigration from all over the world, with Turkey as the most important stop in a neighboring country. As a transit country for migrants from Asia, Middle East and African countries to other countries, the geographical location on migration routes has made Turkey a center of attraction (Kolukırık, 2014: 39). After the events in Syria, which began in March 2011 and increased the density of international mass mobilization since April 29, 2011, Turkey has become the first stopping point for forced migration. On that date, the immigration wave, which started out with 260 asylum seekers arriving at the border crossing in Hatay province, has spread rapidly in a short period of time. It has made the number of refugees outside the camps reach a higher figure than the immigrants within the camps. Thus, Turkey became the host country with the maximum number of refugees in the world starting in 2014, as of 2016. According to the AFAD's report from March 13, 2018, there are 3,547,194 Syrian refugees in Turkey. The Syrian immigrants who come to Turkey preferred dense Mardin, one of the cities that is closest to the Syrian border. According to this report, 2763 Syrians reside in the tent city of Mardin / Midyat. In addition, the number of Syrians outside the camp is reported to be 89,285 (AFAD, 2018).

Regardless of the reason for migration, immigrants have to break away from the social landscape they are used to, and ensure that they adapt to the new situation they are coming into. Although there are individual differences among immigrants in terms of experiencing immigration in terms of the form or reason for immigration, there is a general tendency concerning changes in food culture (Sauner-Leroy, 2012 163). Changes in food culture emerge as immigrants due to radical changes such as moving to a 
social and physical environment completely different from their own culture, changing their livelihoods, and altering the relationship with the tools that they use. Changes in social relations affect the level of shopping, preparation and consumption habits (Goody, 2013: 195).

People always have to make a choice and decide about food in the environment where they live. These choices, when decoupled from their usual environment, can awaken a sense of anxiety. The main issue for people who travel to a different cultural destination is food. That is why food cultures give people a sense of clarity through the classifications and the rules they set, and offer a peaceful way. Immigrants encountering a new social structure in the place they moved to, as a result of this situation, are inevitably affected. The stability and identity aspects of food become more pronounced during migration, and as the dietary habits of immigrants come into contact with both old and the new food systems, both adaptation and change bear importance in terms of food reflecting the social functions (Sauner-Leroy, 2012: 162-163).

Several studies were conducted for Syrian immigrants in Mardin. The effect of Syrian immigrants in Turkey (Çağaptay, 2014), adaptation period of immigrants (Apak, 2014), working processes of informal recruitment (Özkarsl1, 2015), future expectations (Apak, 2015) and the effects of changing dynamics in labor market (Lordoğlu and Aslan, 2016) were conducted for Syrian immigrants in Mardin. The common point of these studies was the economic and social aspects of immigration. The study focused on change and transformation in the food culture of Syrian immigrants who settled to Mardin as a result of the forced migration to Turkey from Syria and aims to characterize the change in dietary habits and perceptions of the existing dining habits of the Syrians after their migration to Mardin. There are several studies conducted on Syrian immigrants in Turkey. These studies are focused on legal rights, their statues, acculturation, etc. The aim of this study is to fill a gap in the literature, by focusing on changes in cuisine and drinking and eating habits. It tries to address how migration affects and shapes the culture of food from a sociological perspective. It is one of the aims of this study to define the changes in the dietary habits after migration and to try to understand the effects of socio-economic and adaptation factors on these changes. Indeed, the age, gender and demographic factors such as duration of time living 
in Mardin as well as one's socio-economic level (education and income) and factors related to the integration process (Turkish/Arabic/Kurdish language dominance, contact with the local people of Mardin) are important parameters in understanding the change in dietary habits.

This work is based on field research carried out in the city of Mardin, located in the Southeastern Anatolia Region. For this purpose, an in-depth interview technique of qualitative research methods and participatory observation were used. The research was carried out from June (2017) to March (2018). The data set of the research carried out by snowball sampling comprises 25 first generation immigrants from different parts of Syria who migrated to Mardin, the majority of whom are university students. The participants, whose ages range from 18 to 60 , migrated to Turkey from various towns in Syria, such as Qamishli, Latakia, Damascus, Homs, Aleppo, Raqqa, Idlib and Jerablus. It was observed that these immigrants moved to various cities in Turkey such as Kilis, Şanlıurfa, Gaziantep, İstanbul, İzmir, Manisa and Midyat first, and from there they fled to Mardin. The reason they moved to Mardin as their second stop is because most of them are students. Of the participants, 15 were male and 10 were female. Interview of research data were obtained by voice recorder. The duration of interviews varied from twenty minutes to one hour. Interviews were transcribed by the researcher. The places where interviews took place were different. University students were interviewed in school and the other interviews took place in their houses. During home interviews, Syrian women offered their traditional dishes to researcher. Although mostly Turkish-speaking people were selected for interview, as the researcher's mother tongue is Turkish, interviews with the non-Turkish-speaking immigrants were not neglected and in-depth interviews were conducted with them with the help of people who speak Arabic or Kurdish. 


\section{THE SHAPING OF DIETARY HABITS IN THE POST-MIGRATION ADJUSTMENT PROCESS: IMMIGRANTS' KITCHEN EXPERIENCES}

Along with migration, a large number of changes in the socio-cultural environment might emerge. These changes are in socio-economic situation, in working life, in lifestyle, forms of eating and drinking, physical activity, and so on. Adaptation to new dietary habits in a variety of immigrant groups can follow very different trajectories. Individual values and dietary habits, worldviews, factors like religious beliefs, new economic conditions, and food availability in the new country may determine the process of adaptation for immigrants (Wandel, Ra ${ }^{\circ}$ berg, Kumar\& Holmboe-Ottesen, 2008: 376-377).

Satia Abouta, Patterson, Neuhouser and Elder (2002: 1107), in their study conducted among immigrant groups in the United States, underlined that some factors are influential in understanding the resulting change in emerging dietary habits. These factors are social-economic and demographic factors and cultural elements. While the socio-economic and demographic factors are comprised of age, gender, socio-economic level, and duration in the new country, employment, fluency of the local language, place of residence, and rural-urban residence in the immigration-receiving country, the cultural factors are comprised of religious beliefs, cultural values and life in an ethnically-closed community. With socioeconomic, demographic and cultural factors combined with the exposure to the new country's culture and changes in the food supply, preparation, and taste differentiation, serious changes in the dining forms of migrants occur.

Changes in the food and eating environments of immigrants also change the trajectories of their food choices. For the immigrants who, as an important landmark in the country's post-war, were forced to emigrate, food choices may change suddenly in their trajectories. These turning points gives rise to radical reconfigurations of patterns of food and beverage selection, which form new food systems which start different personal food trajectories (Terragni, Garnweidner, Pettersen \& Mosdøl, 2014: 275). Based on the fieldwork we conducted in Mardin, in this study, the Syrian immigrants who first had a forced migration experience to all the different provinces of Turkey and from there to Mardin, stated that after arriving in a new country, a number of changes in dietary habits occurred. The most important of these 
changes, in parallel with changing socio-economic situation, is access to good food. The fall in the economic capital of migrants who experienced a loss of status with immigration is one of the main causes of the change in dietary habits. Some participants describe this situation as follows.

"In the past, the rich people could buy anything. For example they could buy meat every day. But they were impoverished when they came here. Maybe once or twice a month they can get meat or they eat more chicken.” (Male, 24, Idlib, student, has lived in Turkey for 5 years)

Sometimes a change in status occurs in the opposite direction; someone who in their own country was engaged in a low-status occupation can increase their status by establishing a business after immigrating and their dietary habits change accordingly. The same participant described this situation as follows:

"In Syria a poor man could eat meat once or twice a month. Now he set up a business here. $\mathrm{He}$ began working. Now he can eat meat every day.” (Male, 24, Idlib, student, has lived in Turkey for 5 years)

Although a decline in socio-economic status affects dietary habits, most Syrian immigrants overcome this challenge in some way and can continue their traditional dietary culture. A participant expresses this situation as follows:

"We did not exactly give up eating meat. We can't do without eating meat once a week. What is tea for you is meat for us." (Male, 25, Latakia, student, has lived in Turkey for 3 years)

During our discussions, the participants stated that the change in the dietary habits occurs due to the style of preparation of food, mostly its appearance, and the changes in taste associated with the use of spices. Participants describe this situation as follows:

"Mardin's local food is too hot and the dominance of green pepper is not nice. Other than that, it is the same. Some things are similar. But our food is different from theirs. It is not hot. We do not add green pepper when we make meals. And we do not add that much hot pepper to the 
potato dish. Their potato dish is too spicy. We can't eat it." (Female, 60, Damascus, housewife, has lived in Turkey for 3 years)

"After returning to Turkey, we did not see much change. I mean, our food culture is similar to Turkey's. We use the same materials. But because of the spices, it tastes different." (Female, 59, Qamishli, Housewife, has lived in Turkey for 3 years)

"There were some differences between the time I immigrated and the time after. There were differences in the taste of our dishes. Food looks very different here. They make everything bigger." (Female, 20, at Jerabulus, student, has lived in Turkey for 4 years)

"Aleppo's cuisine is very different. But it's very similar to Antep's. The stuffed zucchinis and bell peppers are very famous. Their meatballs are famous. Mardin's cuisine is maybe similar to that of Qamishli side so it does not look a lot like ours. It is not similar in terms of dish types. People here cook a chickpea dish. It is watery. I saw it here for the first time in my life. We make felafel. The first time I saw the potato meal here, it was watery. We do not have such food. We cannot eat spicy food. Food here is too spicy." (Male, 24, Aleppo, student, has lived in Turkey for 5 years)

"I'm used to it. But there is some annoyance. Stuffed bell peppers are too big here. They are very small in Syria. Our stuffed eggplant is very small. And we generally only make stuffed eggplant. When I go to the bazaar, everybody buys big bell peppers. When I ask if there is any small bell pepper, the guy asks if I am Syrian. He knows us now.” (Male, 26, Qamisli, Student, has lived in Turkey for 5 years)

According to the statements of the respondents, the difference in appearance between Mardin's meals and the Syrian meals, and the changes in taste due to the use of different spices along with red hot chilli pepper are the main points of the change in the dietary practice of immigrants. In the study conducted by Nicolau et al (2009: 237), on the changes in the food culture of Turkish and Moroccan immigrants in the Netherlands, they mention the importance given by the immigrants to the taste of the food and the 
spices and other ingredients they typically use in their own cuisine. In a sense, special food items and meals are a way of expressing their identity and showing their sense of belonging to the country of origin.

The high prices of, or the inaccessibility of the food used in traditional dishes, lack of information regarding shopping and choice of dishes, and changes in lifestyle and working conditions may result in the differentiation of dining habits of immigrants after immigrating. Especially with the inaccessibility of familiar foods, immigrants face the uncertainty of how they will adapt to the food habits of the new country (Terragni et al, 2014: 274). One of the issues most of the participants underlined is that they cannot access the main ingredients of especially some of the traditional Syrian dishes in Turkey. That the kizbera plant, which is the special spice of the dish Muluhiyye (Molokhia), cannot be found in Turkey constitutes a big problem for them. Participants expressed this situation as follows:

"My problem is that there is a green spice, kizbera plant, which I add to some Syrian dishes. It cannot be found here. Local people here do not use it. I use it in spinach meal, muluhiyye dish and rice. I cannot find it now. Kizbera looks like parsley but the taste is very different. I do without using it because it is not accessible now. I cannot fully enjoy the taste, but it has to be like this. It's missing." (Female, 60, Damascus, housewife, has lived in Turkey for 3 years)

Some participants say that it is very important because it is the main material for this dish, and they order it from friends who go to Syria.

"It is a plant that grows there. This plant used to grow in Turkey too but now we finished it. We now bring it from the border towns. We order it from people who go to Syria, and we have it brought here." (Female, 22, Damascus, student, has lived in Turkey for 5 years)

Some participants also emphasized the change in nutritional forms. The general dietary habits of the Syrians are composed of three main dishes: morning, lunch and dinner. But in general, lunch is at the forefront of meals where the family is gathered together and heartier meals are made. This situation is in line with the evening meal when viewed from the perspective of the Turkish cuisine. The most 
challenging issue for participants is this change in diet. As a result of the fact that it is not possible for the family to gather together at lunch time due to school or work hours, the diet has been changed. However, when they go abroad to visit their families, they continue to have the same diet. Participants expressed this situation as follows.

"Our habits are not what they used to be here. I'm waiting for those who go to school. Now nobody works. In the past those who work used to come home between 3 and 5 . We used to have lunch. But it is not possible now. We have breakfast at one o'clock. My husband comes home at that time. It's not the old order anymore.” (Female, 60, Damascus, housewife, has lived in Turkey for 3 years)

"There was a problem at meal times. For example, we do not eat cooked meals at dinner. We eat cooked meals at around 2 or 3 . In the evening we also eat something light, like breakfast. Now we changed it. Now we eat cooked meals at dinner." (Male, 26, Qamisli, Student, has lived in Turkey for 5 years)

"We generally have a saying. Eat breakfast like a prince. Eat like a king at noon. Eat like a poor man in the evening. When you say poor, eat less. Eat more at lunch. Eat normal in the morning. On the contrary, you eat like a king in the evening." (Male, 21, Qamisli, Student, has lived in Turkey for 3 years)

Friday is the official holiday in Syria, but the official holidays in Turkey are on Saturday and Sunday, and this also affects their diet. In Syria, the Friday breakfasts and dinners of the family were moved to Saturdays, which changed the day following migration. One participant states this situation as follows:

"We have breakfast with the family in the morning on Fridays. You have it on Sunday. It's very important. We make hummus all the time. My family still does. My mom always makes it on every holiday, so every Friday. The families are gathered for the holiday today. We used to go to my grandfather or something. But we changed that. Now we do it on Saturdays." (Male, 26, Qamishli, Student, has lived in Turkey for 5 years) 
Studies about immigrants in general use the concept "acculturation". The process of immigration, together with the migration of both migrating groups is subject to change and mutual interaction in the culture of the region. In this case, most of the time, "acculturation" describes the situation and is considered along with cultural interaction, cultural exchange and cultural adjustment processes (Zafer, 2016: 76). Güvenç (2002: 87) too defines acculturation as the change in two or more cultures due to mutual interaction and the emergence of new syntheses.

The food/nutrition-related processes of acculturation are referred to by the concept of "dietary acculturation". Dietary acculturation is defined as the process which emerges in the adaptation of the immigrant groups to the host country's dietary forms and choice of food (Satia Abouta et al., 2002: 1106). In other words, dietary acculturation is about the individual's dining experiences, challenges and adaptation to the new country's food culture.

Another point is that the distance between two cultures, that is, cross-cultural similarities and differences, is very important in the process of acculturation. The smaller the cultural distance (concerning religion, language, lifestyle and social relationships) is between the immigrant country and the immigration-receiving country, the easier it is for the immigrants to adapt to the host culture (Zafer, 2016: 88). However, although the two countries' languages, religions, lifestyles and dietary habits have similarities, there could be a local twist or differentiation within the common features (Chambers, 2014: 13). The city of Mardin, which forms the sample space of the research, largely bears similarities in terms of ethnicity, language and religion with immigrants' own country's culture. Therefore, the short cultural distance leads the new immigrants to adapt more easily in terms of food culture.

The positive attitude of Mardin city residents towards Syrian immigrants facilitates the process of adaptation. There is no doubt that the causes of this situation are the city's cultural codes, social memory, the same religious belief affiliation, cultural heritage, geographical proximity, kinship relationships with the region continuing since the past, and the multi-ethnic, multi-religious culture experienced in the practice of living together in Mardin. Syrian immigrants are familiar with the region, due to factors such 
as having social ties with the region's culture through ethnicity, language and relatives they had in the past. For the Syrians coming from Qamisli especially, there is cultural familiarity, and they do not experience as many problems in adapting to the food culture as those who come from other regions of Syria (Raqqa, Latakia, Idlip, etc.). In other words, in the interviews, especially the participants coming from Qamisli, which is close to Mardin stated that, due to the small physical distance and cultural distance between Qamisli and Mardin, no critical change occurred in their dietary habits. This is also due to the fact that there are kinship relations based on earlier periods, as these two cities are very close to each other. Some participants expressed the similarity with Mardin's food culture as follows:

"Each region of Syria has a separate food culture. Since we came from the border region, that is Qamisli, it looks a lot like here for us. Actually, we are from Mardin. We used to live in Syria. First my grandfather moved to work there. Then the family of my grandfather moved all together. We were born and bred there. Since my mother made our dishes, she always cooked Mardin dishes. After coming to Turkey we always eat at home. We don't eat out at all. Since my mom makes the dishes, it is not difficult. But in Aleppo, Damascus, Idlib, the food culture changes there. Those who came from Damascus, Aleppo, Rakka- they experience more difficulty." (Male, 21, Qamisli, student, has lived in Turkey for 5 years)

Kinship relationships are a determining factor in choosing routes of migration for Syrian immigrants. Just as the Syrians living in Qamisli primarily prefer Mardin where their relatives live, other immigrants living in other cities of Syria preferred cities which have borders with their own and where their relatives live. One participant states this situation as follows:

"Everyone goes over to their next of kin. Those who came from Aleppo were working as construction workers as it is an industrial city. They went to big cities such as Antep to work. Those who came from the border region usually went to their relatives. They went wherever their relatives lived.”(Male, 21, Qamisli, Student, has lived in Turkey for 3 years) 
As is well known, religion is one of the most important factors affecting the individuals' dietary preferences. Religion, due to the symbolic meanings it invests in food, affects the production, preparation and consumption processes deeply, categorizing foods as edible/hallal and inedible/haram, and with its changes and limitations on existing dietary orders, it holds power over believers' bodies and their dietary forms. Therefore, it is not possible to talk about dietary practices independent of the influence of religion in a community (Gürhan, 2017: 1221). One can assert that, for Muslim immigrants who migrate to a country that has a dietary culture formed in line with the rules of Islam, compared to immigrants who migrate to Christian European countries, their process of adaptation to the food culture is experienced more easily. Especially the presence of a market in Turkey, in terms of access to halal food, where the food industry is shaped according to the prevailing Islamic references, is a big relief to the Syrian immigrants. A participant, who stated that one of his relatives migrated to a European country, maintains that his own adaption to the diet after immigration has been more comfortable:

"My brother went to Europe. He had a lot of difficulty regarding food. They mostly eat at Arab and Turkish restaurants." (Male, 24, Idlib, student, has lived in Turkey for 4 years)

In the study conducted by Ezme on the food culture of Muslim immigrants in United States, it is emphasized that Syrian families prefer Turkish restaurants when they wish to eat out. Because, it is maintained, Syria and Turkey's dietary cultures are very similar as they are neighboring countries (Ezme, 2016: 750-751). Based on both the Syrians in United States mentioned by Ezme's study and data on our research, one can assert that for Syrians the cuisine most similar to their culture and religious references is the Turkish cuisine.

\section{IMMIGRATION, IDENTITY, BELONGING AND FOOD}

As an important element in defining cultures, food is a key element in the immigrant dining experience. When immigrants are in a unfamiliar environment, food forces them to form physical, emotional and cognitive interaction with the surrounding and makes it an important part of daily life (Parasecoli, 2014: 418). Visser, Bailey and Meijering (2015: 614), who maintain that dining experiences are a clear expression of their identities in host countries, also stated that food has the power to represent the country 
they came from. Immigrants migrate with their different cultural norms, foods and eating practices, and the conservative attitude in dietary habits form a "common well-being" feeling with their families in their country by creating a sense of identity (Bailey, 2017: 51). Therefore, as an important indicator of ethnicity, food is one of the most important points that the immigrants are resistant (Harbottle, 1997: 87).

Kanık (2016: 133-136) maintains that identity is not static, but has an aspect that is constantly reproduced and re-constructed, and social mobility, such as migration, create the identity of the subject in an interactive way. In this process the subject can produce an attitude of anxiety regarding the differences while building his/her identity, or can experience these differences and build a versatile identity with more choices. Therefore the hybrid identities emerging as a result of the immigration experience form fusion cuisines which bring together materials belonging to different cultures.

Fischler (1988) also states that it is a way to express otherness and inclusion as the basis of collective identity. Individuals with similar dietary habits resemble each other, and their groups distinguish themselves from other groups. In this respect, food is an important part of the process of building identity. Therefore, the process of adaptation of immigrant individuals to the dietary habits of the new country deeply affects them, sometimes resulting in conflict and tension. Sauner-Leroy, who indicated that the studies on the food culture of the immigrants are mostly about the changes in their dietary habits, maintain that the aforementioned changes can be observed in the changes in the choice/supply, preparation and consumption of food (Sauner-Leroy, 2012: 163). According to her, in these cases, the conservative aspects of most people become salient; immigrants, on one hand, try to accommodate the society they have recently entered, by on the other hand, they do not want to give up the traditional meals of the society they belong to. Therefore, in the dietary habits of immigrants, contradictory aspects, such as conservatism and openness to change, emerge and there is always tension between the adoption and rejection of new dietary habits (Scholliers, 2008: 333-334). 
Food choices enable us to introduce yourself, to shape your identity and to express our distance from others. Changes in eating habits reflect the changes in cultural perception (Koç and Welsh, 2001: 9). Change in the dietary habits of the migrants in the process of migration and their process of adaptation vary. This situation can be explained by the fact that each individual experiences the process of immigration differently. Individuals, having different immigration experiences, may have different processes of adaptation to the cultures of the new society, and therefore different adaptation to their food cultures. This, according to Berry, stems from the immigrants' different strategies of acculturation, and there can be different processes of change and adaptation (Berry, 2005: 704). The basic determinant factors in acculturation strategies are the differentiation in the individual's desire to keep alive their own culture and identity and desire to have a relationship with, and take part in, the host society. Similarly, Oussedik maintains that, in general, a certain time after the immigration, immigrants tend to maintain and protect their dietary habits, which form an important part of their cultural baggage (Oussedik, 2012: 56).

Fieldhouse (2002) states that there are some factors determining the process of change in the dietary habits. These are the social context of migration, new social networks, the strength of the relations with the host country, age, and continuing participation in work and school life. Immigrants are affected more by the host society in public spaces (Visser et al., 2015: 619). In interviews with the participants, it was observed that the immigrants who participate in school and work life adapt more to the food culture of the host society, whereas women who are housewives continue their dietary habits in terms of adaptation. Here the main point is that the immigrants encounter the host culture and they engage in a process of mutual interaction. That housewives only communicate with people from their own culture make them a closed group and thus cultural interaction and harmony is not in question. A similar situation was observed in our study between students who stay at dormitories versus those who stay in homes. All students living in dormitory stated that they have adopted the food culture of Mardin while the students who share a house with Syrian friends stated that they continue to make the traditional Syrian cuisine, and they have not adapted to the food culture of Mardin. 
"I came from Aleppo. I never ate Turkish food. I still haven't eaten it at all. I live in a home. We cook our own meals. Our food is spicier. Our rice is spicier. Yours is tasteless. We have yellow and red rice. We have a spice called "asfur." These spices are not available in Turkey. We call it asfur. It makes our rice yellow." (Male, 23, Aleppo, student, has lived in Turkey for 2 years)

"I came from Aleppo. There are a lot of different dishes here. I had so much difficulty in my city, you can't eat yogurt dishes with tomato sauce. You eat it here. It was a little difficult for my palate." (Male, 24, Aleppo, student, has lived in Turkey for 4 years)

In the other approach, immigrants both protect their own food culture and assert that they have adapted to the Mardin food culture. Those participants engage in cultural interaction and integrate with the new culture they have met.

"I now eat Turkish food. Now I'm used to it. I live in the dorms. I eat everything I find. But when I go to Urfa my mother makes Syrian food. And sometimes she makes Turkish food. It was already like that in the past." (Female, 20, Rakka, student, has lived in Turkey for 3 years)

"When I first came, we did not like Turkish food. But later on, I loved it." (Female, 19, Hummus, student, has lived in Turkey for 3 years)

"I live in the dorms. I always eat Turkish meals here. Those who live in their houses all eat the Syrian meals.” (Male, 24, Aleppo, has lived in Turkey for 4 years)

As we have seen, the change in the dietary habits of students living in dormitory is more apparent. Similarly, Ezme emphasized that the Muslim students in United States are not as conservative as other families in protecting their food culture or lifestyle and they are more open to change (Ezme, 2016: 758). Because they are in a relationship with Americans more than their families, their adaptation processes may be easier. The school environment can be seen as a major cause of this situation.

It was observed that very few participants in the survey (except for students living in dormitories) experienced the Mardin cuisine. Generally, meals are prepared at home and they prefer Syrian dishes. 
Although their traditional dietary habits continue, they are introduced to Turkish meals through the dishes their neighbors bring to them.

"Some neighbors make a cake and bring a slice to us. Sometimes they make rice pudding. But it's not like ours. We make it better." (Female, 35, Damascus, housewife, has lived in Turkey for 3 years)

"Sometimes food is brought in from our neighbors. But we give them too. Our neighbors like our food more. They bring us food in Ramadan but we cannot eat it that much. Their taste does not sit well with us." (Male, 21, Qamisli, Student, has lived in Turkey for 3 years)

The social networks that immigrants build among themselves to maintain their cultural values and habits are to some extent an indication of belonging to their own country (Visser et al., 2015: 620). In our study, the participants stated that they had gathered together sometimes and ate together. These meals are usually a selection of the Syrian dishes. The act of eating and gathering together in the company of traditional meals prepared with ingredients not available or not common in Turkey involves re-building cultural identity.

"Sometimes I go to my friend's house. We meet all together. We usually make Syrian dishes there." (Male, 24, Aleppo, student, has lived in Turkey for 5 years)

"When my husband died, I made a meal for him. I invited all my Syrian friends. They had food. Dishes are also made when there is a Syrian funeral. Everyone goes and eats. It is very nice." (Female, 35, Damascus, housewife, has lived in Turkey for 3 years)

Food is a mediator to protect the connection with home and to maintain the identity for immigrants (Kershen, 2014: 203). Fischler (2011: 536) too considers these communions as a way of re-building identities and forming bonds among relatives, but he states that these are to great extent fictive (artificial) relationships through affinity. Moreover, this can be considered, according to Bailey (2017: 51), as the smell, taste and texture of the food bringing back memories or the normality of the feeling of home. 
The food landscapes of immigrants do not only involve the consumption of the food, but also their integration into the food market of the new country with the food they import from their own country through their attempts to build an identity (Bailey, 2017: 51). In other words, looking at the food landscape of immigrants, it is possible to observe the import of the food from their "home" lands, its preparation, sale, sharing and consumption in order to re-build an identity.

Participants in general stated that they did not have any problem with the preparation of their traditional dishes. The participants, stating that "We can find any food we wish here," prefer small supermarkets which sell Syrian food in order to reach the food special to their own regions. These products are mostly spices and pulses special to their own regions.

Recently, at the small shops which have newly opened in Mardin and belong to Syrians, ingredients and spices not available or rare in Turkey are sold. Moreover, the bread special to Syria and often consumed by Syrians is sold at these supermarkets. Participants stated that they shopped in these small shops in almost every neighborhood in Mardin. These spaces are related to their identities and were promoted as spaces with an identity. Some participants stated that they prefer these venues because they are cheaper than other shopping venues in Mardin, and they feel more comfortable there. In fact, participants expressed that they felt like they were in their own country when shopping in these stores.

"There is a dish called full and I make it. The pulse I add into this meal is not available here. I buy it at the Syrian shop. It comes canned. There are many Syrian shops here. They are in every neighborhood. They're not expensive. Besides, they are cheap.” (Male, 21, Kobani, Student, has lived in Turkey for 4 years)

"There are 6 to 7 Syrian shops in Mardin Yenişehir and upper Mardin. We buy the spices there. They are cheap. 1 liter of olive oil at Turkish supermarkets costs 15 Turkish liras. At Syrian shops it is 6.5 Turkish liras. Their prices are more reasonable than the Turkish supermarkets." (Male, 24, Aleppo, student, has lived in Turkey for 5 years) 
Visser, Bailey and Meijering (2015: 615-616) who conducted a study on Ghanaian immigrants in the Netherlands, state that the migrants call these shops "home" that surround their customers with products coming from Ghana and Africa. These shops are spaces where the immigrants' ethnic identities and sense of belonging appear and create the opportunity for them to re-engage in their own local culture. These spaces also create their own market within the economical market of the host country and form a partially competitive environment. A participant we interviewed expressed a similar description:

"There's a meal called mulûhhiye. It is not available here. There are many Syrian shops for the food that is not available here. We buy the ingredients there. When I go there, I feel like I went to my own country.” (Male, 24, Aleppo, student, has lived in Turkey for 4 years)

In the study conducted by Ezme (2016: 757), she states that there was no change in the dietary habits of the Muslim immigrants after they moved to United States. International supermarkets and Muslim supermarkets play a very important role in this. They can be seen as an adaptation tools for Muslims.

Ingredients, dishes, and practices have the potential to become cultural markers that identify and rally individuals and communities, who frequently display fierce attachment to their food traditions (Parasecoli, 2014: 423). Food brought from home reinforces the sense of belonging of the immigrants through the memories they create (Bailey, 2017: 51). Some participants who went back to Syria to visit their families brought specific food ingredients or special tools used in making food when returning to Turkey. This reinforces their sense of belonging and re-produces their identity:

"I went to Syria to visit my family last week. On my way back I brought kizbera plant for the meal muluhiyye. I invited all my friends. We made the meal and ate together." (Female, 20, İdlip, student, has lived in Turkey for 3 years)

"I have a special tool I brought from Damascus. I use it. I make it finer. Our food is different" (Female, 60, Damascus, housewife, has lived in Turkey for 3 years)

Some college students, among the participants whose families still live in Syria, stated they travel to Syria when they have the opportunity. These immigrants who make the meals they learned in Mardin 
when they returned to their families expressed that they come back to Turkey with food ingredients such as spices, special plants and pulses. Therefore, as Oussedik has pointed out (2012: 57), it can also be regarded as a sign that hybridization works in both directions.

"We stay in the same house with Turkish friends. We cook every day. We created a shift. We make Syrian dishes when it is our shift. They make their own meals when it is their shift. We make meals such as maklube, beans, and muluhiyye. Turkish friends like what we make a lot. We've learned meals from them. I loved the meal called menemen. I learned it from him. When I visited my family I made stuffed grape leaves and the spinach meal for them. They like them too." (Female, 21, Damascus, student, has lived in Turkey for 3 years) 


\section{CONCLUSION}

One of the countries most affected by the global wave of migration that occurred beginning in 2011 in Syria after the war is undoubtedly Turkey. Turkey, being geographically the neighbour of Syria, has become a popular place for immigrants. The city of Mardin, located in the Southeastern Region of Turkey, has become one of the stopping points in the immigration route of immigrants as it is a border town neighboring the city of Qamisli in Syria. Migration is not only spatial displacement of migrants but also a phenomenon which involves social and cultural change and transformation.

Migration separates the individuals both from the physical environment where they live and from the social circle comprised of family, friends and relatives. At the same time, the individual has to abandon the language and culture of the society in which he or she lives. Individuals also suffer status loss when they have to abandon the professions that determined their status, and these losses make it quite difficult for the individual. They make it hard for them to adapt to the culture of the country they migrated to. Moreover, in addition to all the aforementioned difficulties, the individual has a hard time because the dietary culture of the host country is unfamiliar and they cannot find the tastes they are used to. However, immigrants, who abandon their social situations, such as the physical environment, social relationships, language and status, migrate with their own dietary habits. Most of the time, they bring and continue their dietary habits in the new country.

Food, as a basic necessity, is the main issue that immigrants have difficulty with most often after they have migrated and it is an issue they try to solve first. For the Syrian immigrants who were forced to emigrate due to the war which broke out in their own country, their food choices have a sudden change in trajectory, as well as in their socio-economic conditions, status and lifestyle. These radical changes in the dietary habits of immigrants, which occupy an important place in their daily practices, may result in new personal food systems formed by the immigrant individuals.

Just as the food landscapes of the immigrants differ, there are different trajectories in these food landscapes. In this study based on fieldwork in Mardin, it was clearly observed that there have been 
changes in the dietary habits of Syrian immigrants due to the experience of immigration. The most important of these changes, in parallel with changing socio-economic situation, is access to good food. The apparent fall in the economic capital of migrants who experienced a loss of status with immigration is one of the main causes of a change in dietary habits.

In our study, we can say that changes in the dietary habits of immigrants after migration and their strategies against them emerge in three different categories of diet. These are the maintenance of traditional dietary habits, the adaptation to the new country, that is, the adoption of the food habits of the new country, and bi-cultural dietary habits, i.e. hybridization. In interviews, it was seen that for some immigrants, food can turn into a symbol of identity as means to protect and maintain identity, and it can become a tool to express identity. Some participants even stated that they have never had Turkish food since they came to Turkey and they maintain their own traditional food culture.

Especially the appearance of the meal and differences in taste due to changes in the use of spices are the two areas with the most transformation. Unavailability of some food and spices in Turkey which form the main ingredients of the traditional Syrian dishes resulted in the opening of small shops which sell Syrian food products, leading to the re-shaping of the city's food market.

As a result of the kitchen acculturation which defines the immigrant groups' dietary experiences in the host country, the problems they encounter and their process of adaptation to the food culture of the new country, adoption of new dietary habits, or kitchen hybridization may emerge. In our study, it was observed that university students staying in the dormitories in particular are more likely to interact with the host culture and tend to achieve integration with the culture they are new to, and also tend to be hybrid in their dietary habits.

Although in general immigrants face ethnic, linguistic and religious borders in the country to which they migrated, one can assert that both linguistic and religious borders did not give Syrian immigrants who immigrated to Mardin a very hard time. Mardin shows a resemblance to a great extent in terms of ethnicity, culture, language and religion with the culture of the immigrants. Therefore, the lack of 
cultural distance accelerates the process of adaptation of the immigrants to the host culture's food culture. The geographical proximity of both countries, the similarities in food ingredients, similarities in religious beliefs, the closeness of having a shared history, the post-immigration relation with Turkey and the continuing relationship by affinity in the region, and the familiarity with the Turkish food culture also impacts this case. 


\section{5. ÖZET}

$\mathrm{Bu}$ çalışma, Suriye'den Türkiye'ye yapılan zorunlu göç neticesinde Mardin'e yerleşen Suriyeli göçmenlerin yemek kültürlerindeki değişim ve dönüşüm üzerine odaklanmakta ve Suriyelilerin Mardin'e gerçekleştirdikleri göç sonrası beslenme alışkanlıklarındaki değişime ilişkin algılarını ve mevcut yeme-içme alışkanlıklarını karakterize etmeyi amaçlamaktadır. Göçün yemek kültürünü nasıl etkilediği ve şekillendirdiği sosyolojik bakış açısıyla ele alınmaya çalışılmıştır. Göçten sonra oluşan beslenme alışkanlıklarındaki değişiklikleri tanımlamak ve demografik, sosyo-ekonomik ve uyum faktörlerinin bu değişiklikler üzerindeki etkilerini anlamaya çalışmak çalışmanın amaçlarındandır. Nitekim yaş, cinsiyet ve Mardin'de yaşama süresi gibi demografik faktörlerin yanı sıra sosyo ekonomik düzey (eğitim seviyesi ve gelir getirici bir işe girişme) ve entegrasyon süreciyle ilgili faktörler (Türkçe/Arapça/Kürtçe diline hakimiyet, Mardinlilerle temas) beslenme alışkanlıklarındaki değişimi anlamada önemli parametrelerdir.

Bu çalışma, Güneydoğu Anadolu Bölgesi'nde bulunan Mardin kentinde gerçekleştirilen saha araştırmasına dayanmaktadır. Bu amaçla nitel araştırma yöntemlerinden derinlemesine mülakat tekniği ve katılımlı gözlem kullanılmıştır. Araştırmanın verileri 2017 yılı haziran ayından başlayarak aralıklı olarak 2018 yılı mart ayına kadar toplam 10 aylık bir süre içerinde gerçekleştirilmiştir. Kartopu örneklem yoluyla oluşturulan araştırmanın veri setini Suriye'nin farklı bölgelerinden Mardin'e göç etmiş çoğunluğu üniversite öğrencilerinden oluşan 25 birinci kuşak Suriyeli göçmen meydana getirmektedir. Yaşları 18 ile 60 arasında değişen katılımcılar, Kamışlı, Şam, Laskiye, Humus, Halep, Rakka, İdlip, Cerablus gibi Suriye'nin çeşitli kentlerinden Türkiye’ye göç etmişlerdir. Bu göçmenlerin ilk olarak Şanlıurfa, Kilis, Gaziantep, İstanbul, İzmir, Manisa ve Midyat gibi Türkiye’nin çeşitli kentlerine oradan da Mardin'e yerleştikleri görülmüştür. İkinci durak olarak Mardin'e gelişlerinin nedeni çoğunun öğrenci olmasıdır.

Araştırmamızda göç sonrası göçmenlerin beslenme alışkanlıklarındaki değişimler ve bunlara karşı stratejilerinin üç farklı beslenme şekli ortaya çıkardığını söyleyebiliriz. Bunlar geleneksel yemek yeme alışkanlıklarının sürdürülmesi, yeni ülkeye adaptasyon yani yeni ülkenin beslenme alışkanlıklarının 
benimsenmesi ve iki kültürlü beslenme alışkanlıkları yani melezleşmedir. Yapılan görüşmelerde bazı göçmenler için yemek, kimliğini koruma ve devam ettirmenin bir aracı olarak kimlik sembolüne dönüşebilmekte ve kimliğini ifade etmenin bir aracı olmaktadır. Hatta bazı katılımcılar Türkiye’ye geldikleri günden beri hiç Türk yemekleri yemediklerini ve hala geleneksel yemek kültürlerini devam ettirdiklerini belirtmişlerdir.

Özellikle yemeğin görünümü veya baharat kullanımındaki değişime paralel olarak tat farklılıkları en çok değişimin göründüğü alanlardır. Geleneksel Suriye yemeklerinin ana malzemesini oluşturan bazı besin ve baharatların Türkiye'de bulunmaması, Suriyeli gıda malzemelerini satan küçük dükkanların açılmasına neden olarak kentin gıda piyasasının yeniden şekillenmesine neden olmuştur.

Göçmen grupların ev sahibi ülkedeki yeme-içme deneyimleri, karşılaştığı sorunlar ve yeni ülkenin yemek kültürüne adaptasyonu sürecini tanımlayan mutfak kültürleşmesi sonucunda yeni yeme-içme alışkanlıklarının benimsenmesi veya mutfak melezleşmesi de olabilmektedir. Araştırmamızda özellikle yurtta kalan üniversite öğrencilerin daha çok ev sahibi kültürle etkileşime geçerek yeni karşılaştıkları kültürle bütünleşme sağlamaya meyilli oldukları ve beslenme alışkanlıklarında da melezleşmenin olduğu görülmüştür

Genel olarak göçmenler göç ettikleri ülkede etnik, dilsel ve dinsel sınırlarla karşılaşmalarına rağmen Mardin'e göç eden Suriyeli göçmenleri hem dilsel hem de dinsel sınırların çok da zorlamadığını söyleyebiliriz. Mardin kenti, etnisite, dil ve din noktasında göçmenlerin kültürüyle büyük oranda benzerlik taşımaktadır. Dolayısıyla kültürel mesafenin az olması göçmenlerin ev sahibi kültürün yemek kültürüne uyum sürecini hızlandırmaktadır. Hem ülkelerin coğrafi olarak yakın konumlanışı ve böylelikle yemek malzemelerindeki benzerlikler, dini inanışlardaki benzerlikler, ortak bir tarihi geçmişe sahip olmanın verdiği yakınlıklar, bölgede akrabalık ilişkilerinin devam etmesiyle birlikte daha öncesinden Türkiye'yle kurulan bağların olması ve Türk yemek kültürüne olan aşinalık da bu durum üzerinde etkili olmaktadır. 


\section{REFERENCES}

AFAD (2018). Geçici Barınma Merkezleri, on 19 March 2018, Retrieved from https://www.afad.gov.tr/upload/Node/2374/files/13_03_2018_Suriye_GBM_Bilgi_Notu.pdf.

AFAD (2017). Türkiye'deki Suriyelilerin Demografik Görünümü, Yaşam Koşulları ve Gelecek Beklentilerine Yönelik Saha Araştırmas1, on 19 March 2018, Retrieved from https://www.afad.gov.tr/upload/Node/25337/xfiles/17a-

Turkiye_deki_Suriyelilerin_Demografik_Gorunumu_Yasam_Kosullari_ve_Gelecek_Beklentil erine Yonelik_Saha_Arastirmasi 2017.pdf.

Apak, H. (2014). Suriyeli Göçmenlerin Kente Uyumları: Mardin Örneği. Mukaddime, 5 (2), 53-70.

Apak, H. (2015). Suriyeli Göçmenlerin Gelecek Beklentileri: Mardin Örneği. Birey ve Toplum Sosyal Bilimler Dergisi, 5(9), 125-142.

Bailey, A. (2017). The Migrant Suitcase: Food, Belonging and Commensality Among Indian Migrants in The Netherlands. Appetite, Vol. 110, 51-60.

Berry, J. W. (2005). Acculturation: Living Successfully in Two Cultures. International Journal of Intercultural Relations, Vol.29, 697-712.

Chambers, I. (2014). Göç, Kültür, Kimlik. I. Türkmen and M. Beşikçi (Trans.), İstanbul: Ayrıntı.

Çağaptay, S. (2014). The Impact of Syrian Refugees On Southern Turkey. The Washington Institute for Near East Policy.

Ezme, A. T. (2016). Muslım Immigrants Food Culture and Its Effect On Location Preference. Süleyman Demirel Üniversitesi Sosyal Bilimler Enstitüsü Dergisi, CİEP Özel Sayısı, 735- 759.

Fieldhouse, P. (2002). Food and Nutrition; Customs and Culture. Cheltenham, UK: Nelson Thornes Ltd.

Fischler, C. (1988). Food, Self and Identity. Social Science Information, 27, 275-293.

Fischler, C. (2011). Commensality, Society and Culture. Social Science Information, Vol. 50, 3-4.

Goody, J. (2013). Yemek, Mutfak, Sınıf - Karşılaştırmalı Sosyoloji Çalışması. M. Günay Güran (Trans.), İstanbul: Pinhan.

Gürhan, N. (2017). Yemek ve Din: Yemeğin Dini Simgesel Anlamları Üzerine Bir Inceleme. Journal of the Human and Social Science Researches, Vol. 6 (2), 1204-1223. 
Güvenç, B. (2002). Kültürün ABC’si. Cogito, Vol.67, İstanbul, Yapı Kredi.

Harbottle, L. (1997). Fast Food/Spoiled Idendity. Iranian Migrants in The British Catering Trade. (Ed) P. Caplan, in Food, Health and Identity, New York: Routledge.

Kanık, İ. (2016). Gastro Gösteri-Popüler Kültür Ürünlerinde Yemeğin Kültürel Gösterisi. İstanbul: Ayrint1.

Kershen, A. J. (2014). Food in the Biritish Immigrant Experience. Crossings: Journal of Migration and Culture, 5: 2,3, 201-211.

Koç, M., Welsh, J. (2001). Food, Foodways and Immigrant Experience. Paper written for the Multiculturalism Program, Department of Canadian Heritage Program at the Canadian Ethnic Studies Association Conference, Halifax. https://www.researchgate.net/profile/Mustafa_Koc2/publication/253449347_Food_Foodways and_Immigrant_Experience/links/0a85e52fe76e2cff51000000/Food-Foodways-andImmigrant-Experience.pdf.

Kolukırık, S. (2014). Uluslararası Göç ve Türkiye: Yerel Uygulamalar ve Görünümler. Zeitschrift Für Die Welt Der Türken Journal Of World Of Turks, 6 (2), 37-53.

Lordoğlu, K., Aslan M. (2016). En Fazla Suriyeli Göçmen Alan Beş Kentin Emek Piyasalarında Değişimi: 2011-2014. Çalışma ve Toplum, S.2, 789-808.

Nicolaou, M. Doak, C. M., Van Dam, R. Brug, J. Stronks, K. Seidell, J. C. (2009). Cultural and Social Influences On Food Consumption in Dutch Residents of Turkish and Moroccan Origin: A Qualitative Study. Journal of Nutrition Education and Behavior, Vol. 41, 232-241.

Oussedik, S. (2012). Food and Cuisine: Part of The Migration Process. Quaderns de la Mediterrània, Vol. 17, 55-60.

Özkarslı, F. (2015). Mardin'de Enformel Istihdamda Çalişan Suriyeli Göçmenler. Birey ve Toplum Sosyal Bilimler Dergisi, 5(1), 175-192.

Parasecoli, F. (2014). Food, Identity, and Cultural Reproduction in Immigrant Communities. Social Research, 81(2), 415-440.

Satia Abouta, J. Patterson, R., Neuhouser, M. L. and Elder, J. (2002). Dietary Acculturation: Applications to Nutrition Research and Dietetics. Journal of the American Dietetic Association, Vol. 102(8), 1105-1118. 
Sauner-Leroy, M.H. (2012). Yemeğin Değişken Anlamları ve Göç: İstanbul'daki Fransızların Yemek Alışkanlıkları Üzerine Bir Değerlendirme, (Eds.) A. Avcı, S. Erkoç and E. Otman, in Yemekte Tarih Var-Yemek Kültürü ve Tarihçiliği-, İstanbul: Tarih Vakfi Yurt.

Scholliers, P. (2008). Yenilik Ve Gelenek: Gastronominin Önündeki Yeni Ufuk. (Ed). S. Haznedaroğlu, (N. Elhüseyni Trans.) İstanbul: Oğlak.

Terragni, L., Garnweidner, L. M., Pettersen, K. S. and Mosdøl, A. (2014). Migration as a Turning Point in Food Habits: The Early Phase of Dietary Acculturation Among Women from South Asian, African, And Middle Eastern Countries Living in Norway. Ecology of Food and Nutrition, Vol. $53,273-291$.

Visser, S. S., Bailey, A., Meijering, L. (2015). Food, Faith and Community: Social Well-Being of Ghanaian Migrants in The Netherlands. Gender, Place \& Culture, Vol. 22 (5), 608-625.

Wandel, M., Ra ${ }^{\circ}$ berg, M., Kumar, B. and Holmboe-Ottesen, G. (2008). Changes in Food Habits After Migration Among South Asians Settled in Oslo: The Effect of Demographic, Socio-Economic and Integration Factors. Appetite, Vol.50, 376-385.

Yalçın, C. (2004). Göç Sosyolojisi. Ankara: Anı.

Zafer, A. B. (2016). Göç Çalışmaları Için Bir Anahtar Olarak "Kültürleşme" Kavramı. Uludăg Üniversitesi Fen-Edebiyat Fakültesi Sosyal Bilimler Dergisi, Vol.3, 75-92. 